\title{
Standpunt
}

\section{Eienskappe van betroubare wetenskaplike inligting}

In die lig van die onlangse kontroversiële berigte en uitsprake in Suid-Afrika oor die MI-virus en die aansprake oor die wetenskaplike "bewyse" van die oorsake, kan dit baat om opnuut te kyk na maniere waarop die kwalitiet van wetenskaplike kennis beoordeel kan word. Gebruikmakers van wetenskaplike kennis moet in staat wees om te weet hoe hulle "goeie" wetenskap kan onderskei van 'n gesmous met wetenskaplikheid deur gewetenlose of onkundige fortuinsoekers. 'n Groep wetenskaplikes vanuit die akademie, verskillende regerings en die industrie het onlangs 'n aantal punte (TIP, 1999) die lig laat sien waarin hulle die aandag vestig op dinge waarop gelet kan word in die beoordeling van die wetenskaplikheid van resultate. Hier volg enkele voorbeelde.

\section{Stellings van absolute sekerheid}

"Bewyse" in die wetenskap is bykans nooit absoluut nie en meestal gebaseer of getuienis wat op die oomblik beskikbaar is. Verantwoordelike wetenskaplike kommunkeerders vermy terme soos "nooit," "altyd," en "slegs." Hulle gebruik maatstawwe van statistiese betroubaarheid van waardes (bv. standaardafwykings, standaardfoute of betroubaarheidsgrense) om die leser te help om die betroubaaheid en betekenisvolheid van resultate te beoordeel.

\section{Ignorering van belangrike veranderlikes}

In 'n poging om verbande tussen verskillende faktore te toon, word ander dinge wat die uitkoms van die studie kan beinvloed dikwels misgekyk. So byvoorbeeld sal die veralgemeende stelling dat "honger honde gevaarliker is" belangrike faktore soos verskille in honderasse en hoe hulle grootgemaak en opgelei is buite rekening laat. Daar moet veral gelet word op uitsonderings op die reël en kompliserende faktore in 'n ontleding.

\section{Onvermelde of onvoldoende monstergroottes}

Studies wat op klein getalle in die ondersoekgroep gebaseer is, kan tot verkeerde gevolgtrekkings lei. Indien die getalle of die getal herhalings nie vermeld word nie of te laag is, is dit meestal moeilik om die geldigheid van die studie te beoordeel. Goeie wetenskaplike verslagdoening gee altyd 'n aanduiding van die monstergrootte (n).

\section{Gebrek aan bruikbare verwysingstandaarde}

Die vermelding van persentasies sonder goeie verwysingstandaarde of maatstawwe kan misleidend wees. 'n Begrip van wat as te verwagte of normaal beskou kan word, is nodig alvorens vasgestel kan word of 'n situasie abnormaal is. So byvoorbeeld sal 'n $100 \%$ toename in die fisiese abnormaliteite in 'n voëlbevolking ernstig klink, maar dit is nie noodwendig ongewoon of onverwags nie. 'n $100 \%$ toename in 'n groot monster (bv vier voorkomste in 100000 voëls as slegs twee verwag is) mag nie statisties betekenisvol wees of ekologies relevant nie.

\section{Afleiding van oorsaak-gevolg-verhoudings}

Selfs al vind twee gebeure saam plaas, sal die een nie noodwendig die oorsaak van die ander wees nie. Albei mag verband hou met 'n ander faktor wat die ware oorsaak is. Die waarneming dat mense meer dikwels hoede dra wanneer hulle handskoene dra, beteken nie dat handskoene veroorsaak dat mense hoede dra nie. Die dra van sowel handskoene as hoede hou veel eerder verband met ander faktore soos byvoorbeeld koue.

Bevooroordeeldheid van die waarnemer of gevestigde belange

Mense se vooroordele kan onbewustelik die resultate van 'n studie beinvloed of die wyse waaarop dit vertolk word. Die bron se rekord van objektiwiteit is belangrik vir die bepaling van die geldigheid en relevansie van die bevinding. Mense met 'n gevestigde belang in die uitkoms van die studie, hetsy finansieël, polities of sosiaal, kan die interpretasies beïnvloed.

\section{Gevolgtrekkings gebaseer op persoonlike verhale}

Mense maak dikwels foutiewe gevolgtrekkings wat op anekdotes of persoonlike vertellings gebaseer is, veral as dit op 'n bekende of meevoerende manier aangebied word. Verskeie kursusse oor openbare optredes en toesprake beklemtoon die belangrikheid om ' $n$ toespraak of debat te verpersoonlik sodat dit meer oortuigend oorkom. Hoewel persoonlike verhale en ervarings kleur verleen aan 'n tegniese ondersoek of bevinding en dit interessant maak, is dit nie 'n wetenskaplik aanvaarbare bevestiging van die geldigheid van resultate en bevindings nie.

\section{Ongepubliseerde bevindinge}

Dit is normaalweg nie moontlik om die kwaliteit van ongepubliseerde studies te beoordeel nie. Dit is nie algemeen toeganglik vir evaluering nie. Die voorbarige vrystelling of openbaarmaking van ongeverifieërde gegewens of spekulatiewe gevolgtrekkings aan 'n nuushonger pers kan problematies wees. Soms moet navorsers in verleentheid hulle bevindinge terugtrek as die werk nie herhaalbaar is of as die bevindings foutief of gebrekkig bevind word. Die ongelukkige gevolge (bv. blywende wanopvattings, besluite van nie behoorlik gerugsteun is nie en gekompromiteerde reputasies) kan nie in alle gevalle omgekeer of reg gestel word nie.

\section{Geverifieërde kennis}

Indien daar in gedagte gehou word dat wetenskaplike kennis ook omskryf kan word as "geverifieërde kennis" kan alle gebruikers van wetenskaplike bevindinge ook hierdie toets gebruik. Is die werk herhaal, verkieslik deur 'n onafhanklike ondersoeker, en het dit dieselde resultate opgelewer?

\section{LITERATUURVERWYSING}

1. TIP. 1999. Sound Science. Technical Issue Paper, Society of Environmental Toxicology and Chemistry, Pensacola, VSA.

\author{
AJ Reinecke \\ Departement Soölogie \\ Universiteit van Stellenbosch
}

